\title{
THE RESISTANCE OF BACTERIA TO ANTIBACTERIAL DRUGS: A SELECTIVE REVIEW
}

\author{
DAVID H. SMITH \\ Division of Infectious Diseases, Children's Hospital Medical Center, \\ 300 Longwood Avenue, Boston, Massachusetts 02115, USA
}

\begin{abstract}
Bacteria may be resistant to antibacterial drugs because of some alterable property of the cell or the environment ('phenotypic resistance') or some alteration of the usual genetic properties of the cell ('genotypic resistance'). Genotypic resistance can be mediated by a mutation of the bacterial chromosome or the infection of the cell by an extrachromosomal element, e.g. an $\mathbf{R}$ factor. The properties of these resistances are summarized and those of the $\mathbf{R}$ factors of enteric bacilli are reviewed in detail.
\end{abstract}

The resistance of certain bacteria to antibacterial drugs has been appreciated since these drugs were introduced into the medical armamentarium. The basis for bacterial drug resistances was not defined until somewhat later, however. Bacteria are now known to be drug resistant either because of some alterable property of the bacteria or the environment ('phenotypic resistance') or a more permanent property mediated by a chromosomal or extrachromosomal resistance gene ('genotypic resistance'). Certain aspects of each of these phenomena are summarized in this review but particular emphasis is given to the resistance mediated by the extrachromosomal resistance $(R)$ factors of the enteric bacilli.

\section{GENETIC BASIS OF RESISTANCE}

Certain examples of alterable or 'phenotypic' drug resistance of bacteria are presented in Table 1. All antibacterial drugs, with the exception of the polymyxins, inhibit only bacteria actively synthesizing macromolecules. For example, concentrations of streptomycin (Str) that are bactericidal for actively growing bacteria have no effect on the same cells if their protein synthesis is stopped by chloramphenicol $(\mathrm{Cml})$ or the deprivation of a required nutrient ${ }^{1}$.

Although the composition and quantity of the bacterial envelope is genetically regulated, these properties can be altered by manipulations of the environment, which, in turn, may alter the susceptibility of the cell to certain 
Table 1. Examples of 'phenotypic' drug resistance

Properties involved
Antibacterial agent

\section{Bacterial}

Synthesis of macromolecules

Composition of cell surface

2. Environmental $\mathrm{pH}$

Anaerobiosis

High concentration of $\mathrm{Mg}^{2+}$

High concentration of 1 carbon metabolites Sulphonamides
All except polymyxins

Actinomycin D, erythromycin, novobiocin

Erythromycin, aminoglycosides, novobiocin, chlortetracycline, mandelic acid

Aminoglycosides

Novobiocin, tetracycline

antibacterial drugs. For example, actinomycin D, which inhibits most grampositive bacteria at concentrations of only a few micrograms per ml, has little or no activity against enteric bacilli, unless the 'resistant' cells are converted to forms deficient in cell wall (protoplasts) ${ }^{2}$ or are treated with EDTA under conditions which temporarily interrupt the integrity of the lipopolysaccharide portion of the cell wall ${ }^{3}$. Likewise, erythromycin, long

Table 2. Properties of bacterial drug resistances

\begin{tabular}{|c|c|c|}
\hline Property & Mutation of chromosome & $\begin{array}{l}\text { ted by } \\
\mathrm{R} \text { factor }\end{array}$ \\
\hline Molecular basis & $\begin{array}{l}\text { Alteration of usual nucleotide } \\
\text { sequence of DNA. }\end{array}$ & $\begin{array}{l}\text { Non-chromosomal. double- } \\
\text { stranded covalently bonded circles } \\
\text { of DNA. } \\
\text { Utilizes synthetic apparatus of } \\
\text { host cell. } \\
\text { Genetic origin remains undefined. }\end{array}$ \\
\hline Acquisition and loss & $\begin{array}{l}\text { Mutation occurs spontaneously } \\
\text { at a rate of approximately } 1 \text { in } 10^{8} \\
\text { cell divisions. } \\
\text { Lost only by further mutation. } \\
\text { Transmissible to other bacteria of }\end{array}$ & $\begin{array}{l}\text { Acquired only from other bacteria } \\
\text { with factor at rates deternined by } \\
\text { bacteria, } R \text { factor, mechanism of } \\
\text { transfer, environment. } \\
\text { Lost by mutation or segregation. }\end{array}$ \\
\hline Genetic transmission & $\begin{array}{l}\text { Genotype transmitted vertically to } \\
\text { daughter cells; potentially } \\
\text { transmissible to other bacteria of } \\
\text { same genera by conjugation, } \\
\text { transduction or transformation. }\end{array}$ & $\begin{array}{l}\text { Transmissible to daughter cells } \\
\text { and by conjugation or } \\
\text { transduction to bacteria of same } \\
\text { or other genera. }\end{array}$ \\
\hline Phenotype & $\begin{array}{l}\text { Mutation affects resistance only } \\
\text { to drugs with similar mechanisms } \\
\text { of action ; independent mutations } \\
\text { required for resistance to drugs } \\
\text { with different actions. } \\
\text { Mutations affecting resistance to } \\
\text { most drugs have been observed. } \\
\text { Phenotype generally mediated by } \\
\text { alteration of existing structural } \\
\text { element or synthetic enzyme. } \\
\text { Phenotype not usually expressed } \\
\text { for several generations after } \\
\text { mutation. }\end{array}$ & $\begin{array}{l}\text { Factor may contain multiple } \\
\text { structural genes each of which } \\
\text { mediates resistance to a different } \\
\text { drug. } \\
\text { Factors studied to date mediate } \\
\text { only certain resistances. } \\
\text { Phenotype generally mediated by } \\
\text { a drug-inactivating enzyme. } \\
\text { Phenotype expressed within } \\
\text { minutes after factor infects cell. }\end{array}$ \\
\hline
\end{tabular}


known for its 'gram-positive' spectrum, is very effective against spheroplasts of 'resistant' Proteus mirabilis ${ }^{4}$. Bacteria deficient in cell wall are 'phenotypically' resistant to antibacterial drugs, e.g. the pencillins, bacitracin, vancomycin, that inhibit wall synthesis.

The composition of the environmental milieu has a profound effect on the interaction between certain drugs and bacteria. The antibacterial activity of novobiocin, chlortetracycline and mandelic acid is enhanced by acid $\mathrm{pH}$ 's while that of the aminoglycoside drugs and erythromycin is considerably enhanced by alkaline $\mathrm{pH}^{\prime} \mathrm{s}^{5}$. The minimal inhibitory concentration of streptomycin (Str) for Staphylococcus aureus, for example, is 100 times greater at $\mathrm{pH} 7.7$ than at $\mathrm{pH} 5.2^{6}$.

Other environmental factors that affect the antibacterial activity of certain drugs include cation concentration and composition, state of oxygenation, and concentration of nutrients that interfere with the action of the drug.

These are only a few of the defined factors that affect the interaction of drug and bacteria. Indeed, it seems likely that much, if not most, of the resistance of bacteria in nature to drugs is due to 'phenotypic' mechanisms.

Until recently, the genetic basis of bacterial drug resistance was thought to be due to a mutation of the chromosomal gene mediating drug susceptibility. The existence of extrachromosomal genetic elements that mediate drug resistance has now been well documented in S. aureus and the enteric bacilli, and their presence in $S$. albus ${ }^{7}$ and group D Streptococci ${ }^{8}$ is suggested by recent studies. It is not possible to review the properties of all extrachromosomal elements mediating drug resistance, so only those of the $\mathbf{R}$ factors of enteric bacilli will be presented. Some of the more important of these properties are summarized and contrasted to those of the resistances mediated by a chromosomal mutation in Table 2 .

\section{PROPERTIES OF R FACTORS}

\section{Molecular basis}

Whereas a cell with a mutation mediating drug resistance has an alteration in a locus on its chromosome, that infected by an R factor must have some genetic material other than its chromosome. Considerable effort has been expended to define the nature of the $\mathbf{R}$ factor genetic material. The molecular basis of the R factors was presumed to be DNA; therefore, in the initial studies, $\mathrm{CsCl}$ gradients of DNA purified from $\mathbf{R}^{+}$Escherichia coli were examined for a satellite band, vide infra, the $\mathbf{R}$ factor genome. When no satellite DNA was observed, it was reasoned that the DNA of $E$. coli, which is 50 per cent G-C ${ }^{9}$, and $\mathrm{R}$ factors have a similar composition. The studies were therefore repeated with $\mathrm{R}^{+} P$. mirabilis, whose chromosomal DNA has a G-C composition of 36 per cent ${ }^{9}$. A satellite band with a heterogeneous composition of 44-50 per cent was observed in the $\mathrm{CsCl}$ gradients of DNA purified from $\mathrm{R}^{+}$, but not $\mathrm{R}^{-}, P$. mirabilis ${ }^{10,11}$. Following the demonstration that the $\mathbf{R}$ factor genome is a closed circle (see below), the earlier experiments with DNA of $\mathrm{R}^{+} E$. coli have been repeated using gradients which separate linear and circular DNA of the same composition : circular units presumed to be the $\mathbf{R}$ factor genome have been observed in extracts of $\mathrm{R}^{+}$, but not $\mathrm{R}^{-}$. 
E. coli $^{12-14}$. These observations have been supported and extended by recent studies employing the so-called 'mini-cells', the small cellular units that lack chromosomal DNA produced by certain strains of $E$. coli ${ }^{15}$. Mini-cells produced by $\mathrm{R}^{+}$, but not $\mathrm{R}^{-}$, strains contain DNA with the properties described for the $\mathrm{R}$ factor by earlier studies ${ }^{16}$.

Genetic studies ${ }^{17,18}$ have indicated that an $\mathrm{R}$ factor is a composite of two functionally separate units: a transfer unit, or RTF, that mediates conjugal fertility, and, in some cases, restriction of certain phages ${ }^{18}$; and another unit (RD) mediating the drug resistances. Cells with the genetic properties of either or both units can be selected from a parent $\mathbf{R}^{+}$bacterium. The most recently reported studies of $\mathrm{R}$ factor DNA in P. mirabilis indicate that the heterogeneity observed earlier in the sedimentation properties of the $R$ factor DNA is due to the presence of three distinguishable units, presumably the RTF, the RD and the complete R factor ${ }^{12-14}$. Indeed, DNA presumed to be that of the RTF has been identified in cells possessing conjugal fertility $\left(\mathrm{RTF}^{+}\right)$but no drug resistance $\left(\mathrm{RD}^{-}\right)$derived from an $\mathrm{R}^{+}$ strain $^{19}$. Electron micrographs of these purified DNA preparations indicate that, like the E. coli chromosome, the DNA of a complete R factor and that of the composite RTF and RD, are covalently closed circles ${ }^{13,14}$.

\section{Genetic transmission}

Although the interbacterial transfer of an $\mathrm{R}$ factor can be mediated by transduction, it is presumed to occur more commonly in nature by conjugation. A schematic model of the conjugal transfer of $\mathrm{R}$ factors is depicted in Figure 1. The kinetics of such transfer of a wild type $\mathrm{R}$ factor between two strains of E. coli in vitro are illustrated in Figure 2. It is evident that during the course of the experiment the numbers of total donor and recipient bacteria increase in parallel whereas recipient bacteria acquiring an $\mathbf{R}$ factor increase at a much more rapid rate, particularly initially, until they constitute about $0.01-0.1$ per cent of the total population of recipient cells. This experiment also illustrates that the conjugal transfer of $\mathrm{R}$ factors can be prevented by diluting the bacteria to approximately $10^{6} / \mathrm{ml}$, a concentration at which the random interbacterial collisions that are required for specific conjugal contacts are too few to be significant.

In addition to the concentration of donor and recipient bacteria, certain properties of the involved bacteria, the $\mathrm{R}$ factors and the environment affect the conjugal transfer of $\mathbf{R}$ factors. Transfer is much greater between bacteria of the same, rather than unrelated, genera, and mutant bacteria deficient in cell envelope antigens are up to $100 \times$ more effective as donors (and recipients) of $\mathrm{R}$ factors than are their parent cells ${ }^{20}$. Since bacteria deficient in cell envelope antigens are less virulent than their parents, these findings have been cited as evidence for the non-pathogenicity of $\mathrm{R}^{+}$bacteria. Such statements, however, do not take into account the facts that $R$ factors infect cells with normal cell envelopes in vitro and that many of the resistant enteric bacilli isolated from sites of human disease possess $\mathbf{R}$ factors and all cell envelope antigens.

The capacity of $\mathrm{R}$ factors to produce the sexual pilus required for conjugation is normally quite restricted; cells containing mutant $\mathbf{R}$ factors which have an increased capacity to produce such pili are $100-1000 \times$ more 


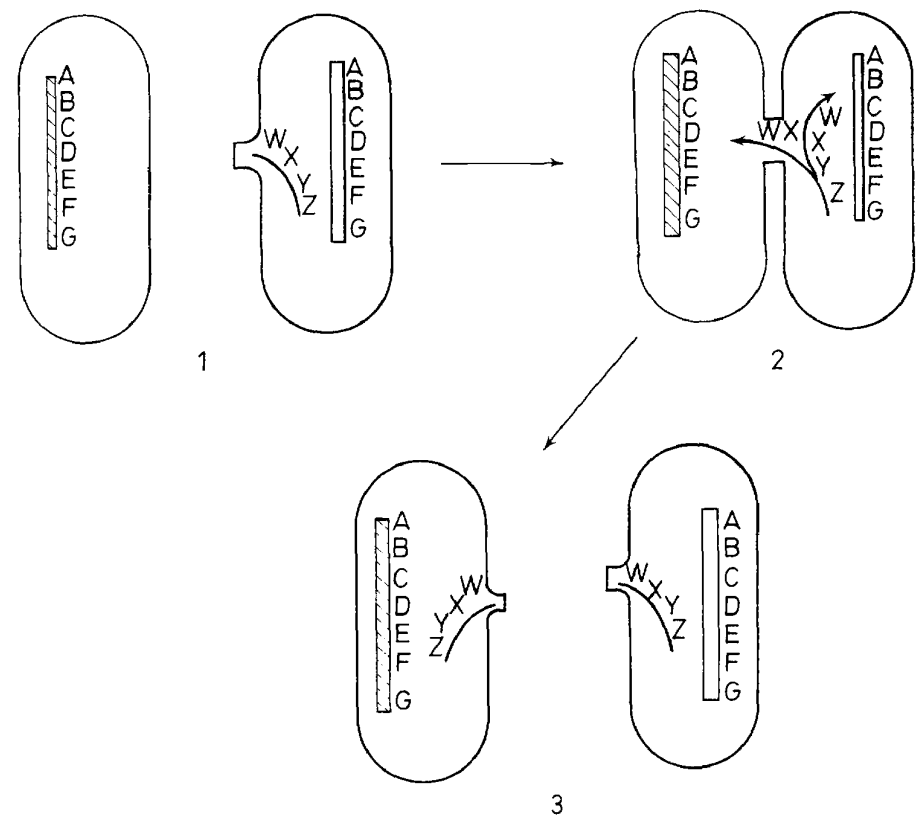

Figure 1. A schematic model for the conjugal transfer of an $\mathbf{R}$ factor. 1. Bacteria with an $\mathbf{R}$ factor that produces a sexual pilus are potential donors of the episome. The large bars $(A-G)$ in each bacterium depict chromosomal genes; the smaller bars $(\mathrm{X}-\mathrm{Z})$ depict $\mathrm{R}$ factor genes. 2 . The sexual pilus of the donor cell attaches to a specific antigen(s) on the surface of the recipient cell. This contact in some inknown way triggers a round of replication of the $\mathrm{R}$ factor, during which one copy of it is transferred to the recipient cell, while the other copy is retained within the donor cell. At the conclusion of the process, 3 , both bacteria possess $R$ factors and are drug resistant and potential conjugal donors of the $\mathrm{R}$ factor.

active as $\mathrm{R}$ factor donors ${ }^{21}$. The state of the current knowledge of this aspect of $\mathbf{R}$ factor transfer has recently been reviewed by the Meynells and Datta ${ }^{22}$. Conjugal transfer of $\mathrm{R}$ factors in vitro is inhibited by a number of substances found in body fluids, non-physiological pH's, anaerobiosis, and inhibitors of DNA synthesis ${ }^{23}$. Considering the number of factors that may adversely affect the conjugal transfer of $\mathrm{R}$ factors, it is not surprising that the kinetics of transfer in vivo differ markedly from those observed in vitro ${ }^{24}$.

\section{Phenotype}

Resistances to sulphonamides (Sul), tetracycline (Tet), Cml and Str were the first associated with $\mathrm{R}$ factors. Subsequently, resistance to certain nonantibiotic antibacterial agents, e.g. bacteriophages, salts of heavy metals, and ultra-violet light, and most of the other antibacterial drugs used to treat infections caused by enteric bacilli were found to be mediated by certain $\mathrm{R}$ factors (Table 3). Conspicuously absent from this list of resistances. however, are those to the furan derivatives and nalidixic acid (Nal), although the liberal use of these drugs in medicine or agriculture might be presumed 


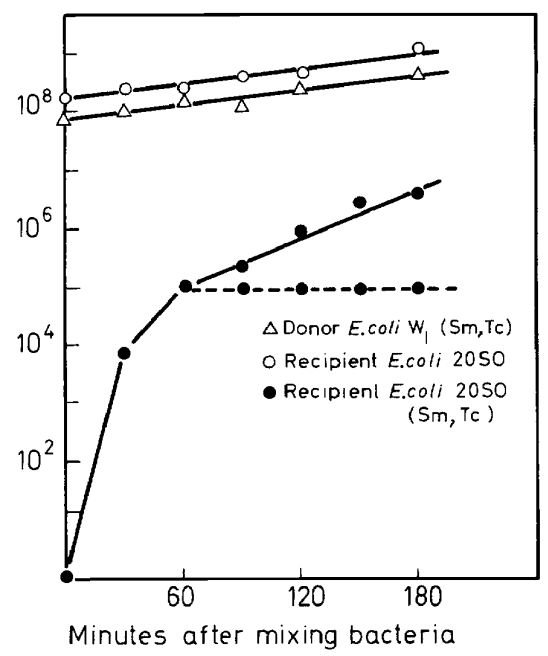

Figure 2. Kinetics of transfer of an $\mathrm{R}$ factor in vitro. Equal volumes of cultures of $E$. coli $K_{12}$ $W_{1}$ infected with an $\mathrm{R}$ factor and $E$. coli $K_{12} 2050$ in exponential growth in broth were mixed, and at intervals, aliquots were removed, diluted and plated on eosin and methylene blue lactose agar (EMB) to determine total viable cells of each parent, and on agar containing tetracycline, $20 \mu \mathrm{g}$ per millilitre, to determine the number of resistant recipient bacteria. The parent bacteria could be differentiated on EMB agar because the donor strain is $l a c^{+}$, whereas the recipient strain is $\mathrm{lac}^{-}$. The selective medium permitted growth only of tetracycline-resistant recipient bacteria because the recipient strain had a high-level resistance to streptomycin (1 $\mathrm{mg}$ per millilitre) whereas the donor strain had a low-level resistance to streptomycin (50 to $100 \mu \mathrm{g}$ per millilitre). After one hour of incubation an aliquot was removed from the culture, vigorously agitated for sixty seconds on a Vortex mixer to separate mating bacteria, and then diluted to a thousandfold in broth to prevent further pair formation. Aliquots of this culture were plated as indicated above and the results are denoted by the dashed line. From D. H. Smith. New Eng. J.

Med. 275, 626 (1966)

to have provided ample opportunity for the selection of $\mathrm{R}$ factors with these resistances. The possibility that this negative association is related to the synthetic rather than natural origin of the furans and Nal remains a matter of speculation. All other drugs, with the exception of sulphonamides, to which $\mathrm{R}$ factors mediate resistance are produced by microorganisms found in nature. The 'natural' antibiotics may, therefore, have been exerting a selective pressure on enteric bacilli and their evolution for a considerably longer period than compounds only recently synthesized and introduced into nature by man. A number of other possible explanations for this negative relationship exist, however, including the possibility that all genes mediating resistance to the furans and $\mathrm{Nal}$ are recessive when introduced into bacteria possessing a gene mediating susceptibility to the respective drugs. The genetics of resistances to these drugs has not been studied in bacteria isolated from nature, but the locus mediating Nal resistance in $E$. coli selected in the laboratory is recessive when introduced into $\mathrm{Nal}^{\mathrm{s}} \mathrm{E}$. coli by an $\mathrm{F}$ factor ${ }^{25}$. Definition of this type of question regarding the origin of $\mathrm{R}$ factor genes is of practical, as well as theoretical, importance. 
Table 3. Biochemical basis for resistance to antibacterial agents

\begin{tabular}{|c|c|c|}
\hline \multirow[b]{2}{*}{ Agent } & \multicolumn{2}{|c|}{ Genetic basis of resistance } \\
\hline & Chromosomal & $\mathrm{R}$ factor \\
\hline Sulphonamides & $\begin{array}{l}\text { Inhibits tetrahydropteroic } \\
\text { acid synthesis }\end{array}$ & Unknown \\
\hline Penicillins (cephalosporins) & $\begin{array}{l}\text { Decreased permeability; } \\
\text { rarely inactivation by } \beta \text { - } \\
\text { lactamase }\end{array}$ & Inactivation by $\beta$-lactamase \\
\hline Streptomycin & $\begin{array}{l}\text { Altered } 30 \mathrm{~S} \text { ribosomal } \\
\text { protein }\end{array}$ & $\begin{array}{l}\text { Inactivation by } \\
\text { phosphorylation, adenylation }\end{array}$ \\
\hline Chloramphenicol & Decreased permeability & Inactivation by acetylation \\
\hline Tetracycline & Decreased permeability & Decreased permeability \\
\hline Kanamycin & Altered $30 \mathrm{~S}$ ribosome & $\begin{array}{l}\text { Inactivation by } \\
\text { phosphorylation, acetylation }\end{array}$ \\
\hline Spectinomycin & Altered $30 \mathrm{~S}$ ribosome & Inactivation by adenylation \\
\hline Gentamicin & Altered $30 \mathrm{~S}$ ribosome & Inactivation by adenylation \\
\hline
\end{tabular}

The epidemiology of $\mathrm{R}$ factors is beyond the scope of this review. It must be emphasized, however, that $\mathbf{R}$ factors, described originally as mediators of resistance to three or more drugs, often mediate resistance to only one or a few drugs. Furthermore, the patterns of resistance mediated reflect, in part, the environment in which the host bacteria were isolated. Thus, $R$ factors mediating the patterns of resistance described originally in Japan are rarely observed in bacteria isolated in the United States ${ }^{26-28}$.

\section{BIOCHEMICAL BASIS FOR RESISTANCE}

Table 3 contrasts certain of the known biochemical mechanisms for the resistances mediated by $\mathbf{R}$ factors and by chromosomal mutations. Whereas most of the studied $R$ factor resistances are mediated by enzymes that inactivate the respective drugs, the studied resistances due to chromosomal mutations are generally mediated by altered structural proteins or synthetic enzymes. It should be emphasized, however, that chromosomal resistance has been studied, until recently, in only a few species of a few genera of bacteria, all of which have been selected for resistance in the laboratory. The recent reports that drug-resistant strains of certain $\mathrm{R}^{-}$E. coli, P. mirabilis and Pseudomonas aeruginosa produce $\beta$-lactamase ${ }^{29}$, chloramphenicol acetyl transferase ${ }^{30,31,38}$ and kanamycin phosphorylase ${ }^{32}$, respectively suggest that the earlier studies on the biochemical basis of drug resistance following chromosomal mutations of enteric bacilli may have been incomplete, and they emphasize the importance of studying resistant bacteria isolated from nature.

It might be presumed that resistance mediated by a drug-inactivating enzyme should be expressed as soon as the enzyme is synthesized, whereas that mediated by an altered or 'drug-resistant' protein may not be expressed until its concentration surpasses that of the protein mediating susceptibility to the drug. It is, therefore, not surprising that all of the $\mathrm{R}$ factor resistances studied are expressed within a fraction of a generation time of the host cell following the introduction into the cell of an R factor, and that, on the other 
hand, many resistances mediated by chromosomal mutation, e.g. Str resistance, are not expressed for several generation times following the mutational event or the introduction of the mutant gene by genetic transfer.

The biochemical basis for the $\mathbf{R}$ factor-mediated resistances have been the subject of experimentation in many laboratories, and many of these mechanisms have been defined.

Resistance to $\mathrm{Cml}$ (Figure 3) is produced by an enzyme (Table 4) that<smiles>O=C(NC(=O)[C@H](O)c1ccc([N+](=O)[O-])cc1)C(Cl)Cl</smiles>

Figure 3. Molecular structure of chloramphenicol

Table 4. Properties of $\mathrm{Cml}$ acetyltransferase

Location in the cell : intracellular

Production : constitutive

Molecular weight : 78000

pH optimum : 7.8

Substrate affinity: D, threo isomers of $\mathrm{Cml}$ with an acyl group at 2- $\mathrm{NH}_{2}$ position

$K_{m}$ for $\mathrm{Cml}: 6.1 \times 10^{-6} \mathrm{M}$

Products: 3-acetoxy and 1-3-acetoxy $\mathrm{Cml}$

From W. V. Shaw. J. Biol. Chem. 242, 687 (1967); Y. Suzuki and S. Okamoto. J. Biol. Chem. 242, 4722 (1967).

catalyses the sequential formation of 3-acetoxy and 1,3-acetoxy $\mathrm{Cml}^{30,33}$. The $\mathrm{Cml}$ acetyltransferase (CAT) attacks only those $\mathrm{Cml}$ congeners with the $\mathrm{D}$, threo configuration; it also requires a substrate that contains an acyl group at the 2-amino position of the molecule, but it tolerates substrates in which the 1-phenyl group is substituted (Table 5) ${ }^{34}$. Thus, while the enzyme attacks many biologically inactive analogues, it acetylates all known $\mathrm{Cml}$ congeners that have antibiotic activity. The available data indicate that both acetoxy compounds are produced by one enzyme. The reduced antibacterial activity of these compounds, like those of previously described nonantibacterial $\mathrm{Cml}$ analogues ${ }^{35}$, appears to be due to their reduced binding affinity for ribosomes ${ }^{36}$, the site of action of $\mathrm{Cml}$.

Following the documentation of CAT as the basis for the $\mathrm{R}$ factormediated resistance, this enzyme has been observed in certain $\mathrm{R}^{-}$strains of enteric bacilli. Some, but not all, $\mathrm{Cml}$ 'sensitive' $P$. mirabilis produce small amounts of $\mathrm{CAT}^{37}$. Mutants of these strains selected for high levels of resistance to $\mathrm{Cml}$, produce higher concentrations of CAT than do the parent strains. Jacobson and Shaw have reported that the CAT of $P$. mirabilis and $\mathbf{R}$ factors are similar with respect to molecular weights, substrate specificities, 
THE RESISTANCE OF BACTERIA TO ANTIBACTERIAL DRUGS

Table 5. Assay of acetyl acceptor activity of CM congeners

\begin{tabular}{lr}
\hline \multicolumn{1}{c}{ Compound } & Relative activity \\
\hline A. Stereoisomers & \\
D-threo & 100 \\
L-threo & 1 \\
D-erythro & 1 \\
B. Analogues with p-phenyl substitutions & 100 \\
$p$ - $\mathrm{NO}_{2}(\mathrm{CM})$ & 68 \\
$p-\mathrm{CH}_{3} \mathrm{SO}_{2}^{-}$ & 81 \\
$p-\mathrm{CH}_{3} \mathrm{CO}^{-}$ & \\
C. Analogues with other substitutions & 73 \\
$\mathrm{HOCH}_{2} \mathrm{CO}^{-}$at 2-amino & 1 \\
$\mathrm{CH}_{3} \mathrm{CO}^{-}$at 1-hydroxyl & 2 \\
$\mathrm{CH}_{3} \mathrm{CO}^{-}$at 3-hydroxyl & 0 \\
$\mathrm{CH}_{3} \mathrm{CO}^{-}$at 1- and 3-hydroxyl & 0 \\
$\mathrm{None}^{-}$at 2-amino & \\
\hline
\end{tabular}

pH optimum, reaction products, heat stability and reactivity with anti-CAT ( $R$ factor) rabbit antisera; they differ only in the $K_{m}$ for $\mathrm{Cml}: 1.8 \times 10^{-5} \mathrm{M}$ for the CAT of $\mathrm{R}^{-} P$. mirabilis and $0.68 \times 10^{-5} \mathrm{M}$ for $\mathrm{R}^{+}$strains $^{38}$. These data suggest an evolutionary relationship between the presumed chromosomal gene and the R factor gene that mediates CAT synthesis, but further genetic studies will be needed to prove that the CAT locus of $R$ factors came originally from $P$. mirabilis. The properties of the CAT produced by an apparently $\mathrm{R}^{-}$strain of $E$. coli $\mathrm{b}$ maintained in the laboratory of Sompolinsky ${ }^{31}$, but not in that of other investigators, remain to be described. CAT with similar, but not identical, properties is also produced by $\mathrm{Cml}$ resistant $S$. aureus ${ }^{39}, S$. albus $^{40}$, and group D Streptococci ${ }^{8}$, and, in each case, the genetic apparatus for these enzymes appears to be located on an extrachromosomal element.

Table 6. Relationship between $\mathrm{R}$ factor enzyme levels and carbon source in medium ${ }^{\mathrm{a}}$

\begin{tabular}{|c|c|c|}
\hline \multirow{2}{*}{$\begin{array}{c}\text { Carbon source } \\
(0.2 \text { per cent })\end{array}$} & \multicolumn{2}{|c|}{ Enzyme specific activities } \\
\hline & $\mathrm{CAT}^{\mathrm{b}}$ & SAT $^{\mathbf{c}}$ \\
\hline Glycerol & 4560 & 3.54 \\
\hline Glucose & 780 & 0.79 \\
\hline Glucose-6-phosphate & 980 & 0.39 \\
\hline Arabinose & 1460 & 1.08 \\
\hline Mannitol & 1520 & 0.99 \\
\hline Rhamnose & 3120 & 0.33 \\
\hline
\end{tabular}

- The strain used was E. coli AB1932-1/JJ1. The R factor JJ1 confers resistance to $\mathrm{Cml}$, Str, Sul and Mer.

b nmoles $p$-nitro-m-carboxythio-phenol produced per min per mg protein at $25^{\circ} \mathrm{C}$.

cpm of $\alpha^{-32} \mathrm{P}$-ATP pr $\mu \mathrm{g}$ aliquot which adsorb to a $1 \mathrm{~cm}^{2}$ piece of phosphocellulose paper per $\mu \mathrm{g}$ protein per min at $37^{\circ} \mathrm{C}$.

From J. Harwood and D. H. Smith. Biochem. Biophys. Res. Commun. 37, 57(1971). 
There have been few studies of the regulation of $\mathbf{R}$ factor enzymes, but the data of Harwood and Smith indicate that the synthesis by $E$. coli of the $\mathbf{R}$ factor-mediated CAT is affected by the carbon source in the medium: the specific activity of the enzyme in cells grown in glucose or glucose-6phosphate is $\frac{1}{3}-\frac{1}{5}$ that of cells grown in glycerol or succinate (Table 6) ${ }^{41}$. This catabolite repression is eliminated by the addition of $5 \mathrm{~mm}$ cyclic $3^{\prime} 5^{\prime}$ AMP to the culture medium (Table 7). The role of cyclic AMP on the regulation of CAT synthesis is supported and emphasized by the very low specific activity of the enzyme in a mutant strain of $E$. coli that is deficient in cyclic AMP (Table 8). Catabolite repression of the synthesis of an $\mathrm{R}$ factor enzyme was not anticipated since, to our knowledge, this is the first report of constitutive enzyme synthesis being subject to this form of control, and since such enzymes have no known catabolic function. These results may, therefore, provoke a re-examination of these enzymes' evolutionary origins and/or role in the cell.

Table 7. Relationship between enzyme levels and adenine nucleotides added to medium ${ }^{\mathrm{a}}$

\begin{tabular}{llc}
\hline \multicolumn{1}{c}{ Carbon source (0.4 per cent) } & Nucleotide (5mM) & Specific activities of CAT \\
\hline Glycerol & 0 & 1800 \\
Glycerol & 5' AMP $^{\prime}$ cyclic 3'5 AMP & 2000 \\
Glycerol & & 3600 \\
Glucose & 0 & 460 \\
Glucose & $5^{\prime}$ AMP & 580 \\
Glucose & cyclic 3' $5^{\prime}$ AMP & 4200 \\
\hline
\end{tabular}

The strain used was $E$. coli $3000 / \mathrm{JJ} 1$.

b nmoles $o$-nitrophenol produced per min per $\mathrm{mg}$ protein at $25^{\circ} \mathrm{C}$.

c units as in Table 6.

From J. Harwood and D. H. Smith. Biochem. Biophys. Res. Commun. 37, 57 (1971).

$\mathbf{R}$ factors produce two enzymes that in the presence of ATP inactivate Str by attacking the 3-OH group of the $N$-methyl glucosamine moiety of the drug (Figure 4). The better studied of these enzymes, the Str adenylate

Table 8. Relationship between CAT levels and cyclic $3^{\prime} 5^{\prime}$ AMP $^{a}$

\begin{tabular}{lclc}
\hline \multirow{2}{*}{ E. coli $K_{12}$ strains } & \multicolumn{2}{c}{ Medium supplements } & \multicolumn{1}{c}{ Enzyme specific } \\
& Carbon source $(0.4$ per cent) & Nucleotide 3mM & activities of CAT \\
\hline 1 100/JJ1 (parent) & Clycerol & 5' AMP & 3000 \\
& Glycerol & cyclic AMP & 4300 \\
& Glucose & 5' AMP & 980 \\
& Glucose & cyclic AMP & 4450 \\
$5336 / \mathrm{JJ1}$ (adenyl & Glucose & 5' AMP & 260 \\
cyclase-deficient mutant) & Glucose & cyclic AMP & 7000 \\
\hline
\end{tabular}

- Expressed as described in Tables 6 and 7

From J. Harwood and D. H. Smith. Biochem. Biophys. Res. Commun. 37, 57 (1971). 


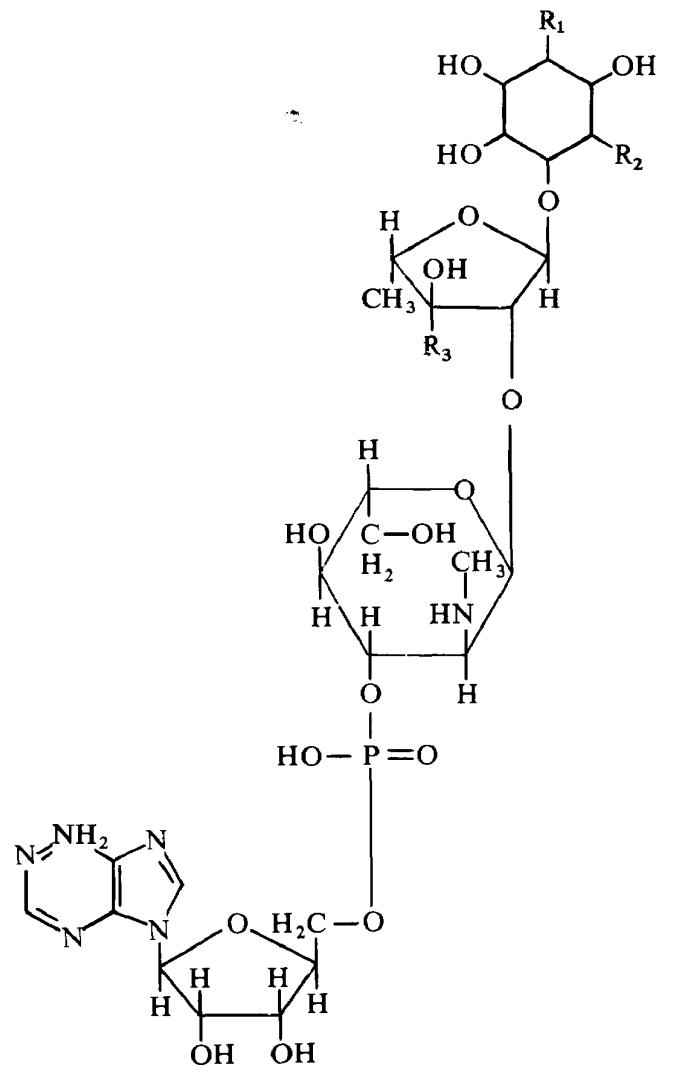

Figure 4. Molecular structure of streptomycin

transferase (SAT) ${ }^{42-44}$ (Table 9) attacks Str, a number of Str analogues and spectinomycin (Spc), an aminoglycoside antibiotic that differs from Str in that it is bacteriostatic and does not promote genetic miscoding ${ }^{45}$; SAT does not attack the neomycins, kanamycins or gentamicins, however. Like all other R factor enzymes studied, the SAT is produced constitutively, and

Table 9. Properties of Str adenylate transferase

Location in the cell : periplasmic space

Production : constitutive

Molecular weight : 33000

$\mathrm{pH}$ optimum : $8.0-8.5$

Substrate: deoxyribo- or ribo-ATP

$K_{m}$ for Str: $2.5 \pm 0.5 \times 10^{-5} \mathrm{M}$

$K_{m}$ for Spc: $2.0 \pm 0.7 \times 10^{-5} \mathrm{M}$

Products: Str or Spc adenylate

R. Benveniste, T. Yamada and J. Davies. Infect Immun. 1, 109 (1970). D. H. Smith, J. A. Janjigian, N. Prescott and P. W. Anderson. Infect. Immun. 1, 120 (1970). 
preliminary studies indicate that its synthesis, like that of CAT, is also catabolite repressed (Table 5$)^{41}$. The other defined Str-inactivating enzyme phosphorylates the drug ${ }^{46}$. This enzyme has no detectable activity for Kan, Neo or Gen $\mathrm{C}$ but it does phosphorylate Gen $\mathrm{A}^{47}$; unlike the SAT, it does not attack Spc. Str phosphorylating activity has recently been described in $P$. aeruginos $a^{32}$ and $S$. aureus ${ }^{48}$ by Umezawa's group, and it will be of interest to hear more about the biology of these enzymes as well as their relation to that produced by $\mathrm{R}^{+}$enteric bacilli. Davies has found that the lack of antibacterial activity of Str adenylate and Str phosphate is due to their markedly reduced binding affinity for ribosomes (personal communication).

$\mathrm{R}$ factors produce two enzymes that in the presence of ATP inactivate kanamycin (Kan) by acetylating the 6-amino group ${ }^{49}$ or phosphorylating the 3-OH group ${ }^{50}$ of the 6-amino-6-deoxy-D-glucose moiety (Figure 5). The Kan phosphorylase is genetically and biochemically distinct from the Str phosphorylase, and, not surprisingly, the Kan acetyltransferase (KAT)

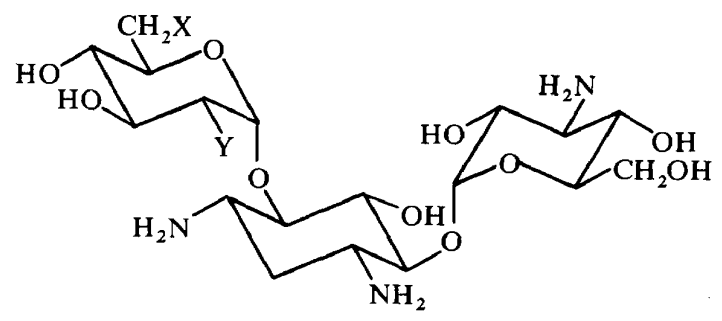

$$
\begin{array}{ll}
\text { Kanamycins } & \text { A: } \mathrm{X}=\mathrm{NH}_{2}, \mathrm{Y}=\mathrm{OH} \\
& \text { B: } \mathrm{X}=\mathrm{NH}_{2}, \mathrm{Y}=\mathrm{NH}_{2} \\
\text { C: } \mathrm{X}=\mathrm{OH}, \mathrm{Y}=\mathrm{NH}_{2}
\end{array}
$$

Figure 5. Molecular structure of the kanamycins

is not related to the CAT. The site attacked by the KAT is relatively unique to Kan and thus the enzyme does not inactivate structurally similar aminoglycoside drugs in which the above moiety is substituted by other groups, e.g. Kan C (glucosamine), Neo (2-6-diamino, 2-6-dideoxy-D-glucose) or Par (2-6-diamino 2-hydroxy-6-dioxy-D-glucose ${ }^{49}$. KAT does acetylate gentamicin (Gen) $\mathrm{C}_{1 \mathrm{a}}$ and $\mathrm{C}_{2}$, however (Figure 6) (Davies, J., personal communication). The Kan phosphorylase attacks the $C_{3}$ group of the 6-amino-6deoxy-D-glucose moiety of Kan and Neo, and of the glucosamine moiety of $\operatorname{Par}^{50}$. Thus, the enzymatic basis for the Kan resistance of certain enteric bacilli can be preliminarily evaluated by the pattern of resistance to these related aminoglycoside drugs.

Gen $\mathrm{C}$ has no oxygen function at the $\mathrm{C}_{3}$ position of the methyl amino sugar $^{51}$ and, thus, is not attacked by the SAT, Str phosphorylase or Kan phosphorylase. The acetylation of Gen $\mathrm{C}$ by the KAT reduces but, unexpectedly, does not eliminate, the antibacterial activity of the drugs (Davies, J., personal communication); thus, bacteria with an $\mathbf{R}$ factor producing this enzyme are resistant to Kan but not Gen. Martin, at a recent 


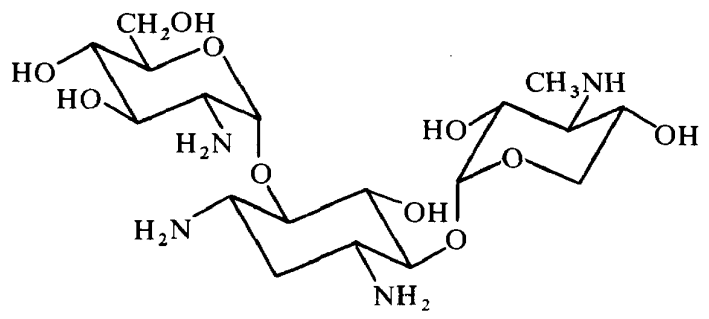

Gentamicin A

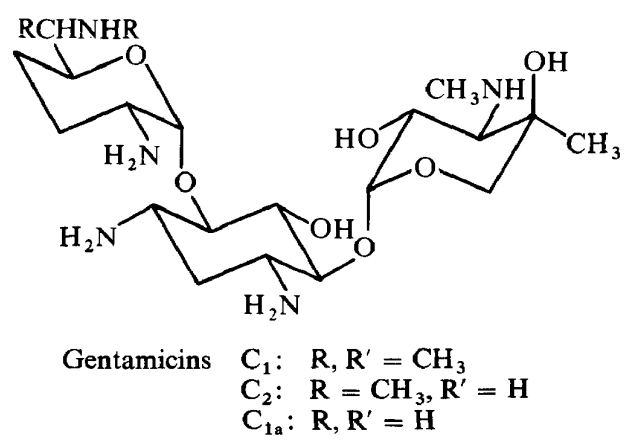

Figure 6. Molecular structure of the gentamicins

symposium on gentamicin, reported that certain highly Gen resistant strains of Klebsiella isolated in clinics in the United States contain an $\mathbf{R}$ factor that apparently inactivates Gen and Kan but not Str. This resistance has been found to be mediated by an enzyme that adenylates the drug ${ }^{63}$. This finding is rather sobering since Gen has been used commercially in this country for less than two years, and it re-emphasizes the need for a better definition of the origin of $\mathbf{R}$ factor genes.

Many enteric bacteria produce $\beta$-lactamases that inactivate certain penicillins and/or cephalosporins. Several recent reports have clarified the questions of the number and type of these enzymes, and their relationship to bacterial resistance. When Jack and Richmond ${ }^{52}$ studied the profile, charge, and sensitivity to $p$-chlormercuribenzoate, cloxacillin and antiserum of the $\beta$-lactamases produced by $4 \mathrm{~b}$ ampicillin resistant strains of eight genera of enteric bacilli, they found eight distinct enzymes (Table 10). Some were predominantly 'penicillinases', other 'cephalosporinases', while others were equally active against penicillins and cephalosporins. Twelve of the 46 strains, including some producing three of the eight types of $\beta$-lactamases, transferred by conjugation the gene(s) mediating the synthesis of these enzymes. The prevalence and distribution of $\mathbf{R}$ factors producing these enzymes has not yet been defined ${ }^{53-55}$. The carbenicillin resistance of certain $P$. aeruginosa strains isolated in Great Britain ${ }^{56}$ is mediated by one of the eight enzymes found in the Enterobacteriaciae, and is produced by an $\mathbf{R}$ factor $^{57,58}$ 
DAVID H. SMITH

Table 10. Properties of the $\beta$-lactamases detected among enteric bacteria

\begin{tabular}{|c|c|c|c|c|c|c|c|}
\hline \multicolumn{4}{|c|}{ Substrate profile } & \multicolumn{3}{|c|}{ Sensitivity to } & \multirow{2}{*}{$\begin{array}{c}\text { Electrophoretic } \\
\text { mobility } \\
(\mathrm{cm} / \mathrm{h})\end{array}$} \\
\hline $\begin{array}{c}\text { Enzyme } \\
\text { Type }\end{array}$ & Pcn & Amp & Cep & $\begin{array}{c}\text { Anti-TEM } \\
\text { Serum }\end{array}$ & $\mathrm{pCMB}$ & Cloxacillin & \\
\hline 1 & 100 & 150 & 180 & + & - & + & -1.6 \\
\hline 2 & 100 & 0 & 8000 & - & - & + & +0.1 \\
\hline 3 & 100 & 120 & 150 & - & + & - & +0.1 \\
\hline 4 & 100 & 125 & 60 & - & + & - & -1.0 \\
\hline 5 & 100 & 0 & 350 & - & - & + & +0.7 \\
\hline 6 & 100 & 160 & 15 & \pm & - & + & -0.2 \\
\hline 7 & 100 & 180 & 0 & 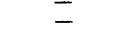 & - & + & -0.6 \\
\hline 8 & 100 & 170 & 70 & - & + & - & -0.6 \\
\hline
\end{tabular}

From G. W. Jack and M. H. Richmond. J. Gen. Microbiol. 61, 43 (1970).

There is little question that the $\beta$-lactamases of $R$ factors contribute to the ampicillin and cephalosporin resistances of host bacteria. On the other hand, non-enzymatic mechanisms, due, at least in part, to alterations in permeability to the drugs, can mediate these resistances in enteric bacilli in the absence of $\beta$-lactamase. It is therefore of interest that some $\mathbf{R}$ factors can produce such non-enzymatic resistance to the penicillins ${ }^{59}$.

\section{Origin}

The results of recent studies are beginning to define the origin of the $\mathrm{R}$ factor genome. Relationship to other bacterial plasmids, e.g. colicinogenic factors ${ }^{60}$ and bacteriophage, is indicated by the recombination of $R$ factors with these elements. That some part of the $\mathrm{R}$ factor genome is related to the chromosome of bacteria is evidenced by the integration of certain $\mathbf{R}$ factors into the $E$. coli chromosome ${ }^{61}$ and the discovery of an R factor bearing a complete lac operon ${ }^{62}$. The biochemical similarities between certain enzymes produced by $\mathbf{R}$ factors and apparently $\mathbf{R}^{-}$bacteria suggest, but do not prove, a common origin of the genes producing these enzymes. The available data do not indicate, for example, whether the $\mathbf{R}$ factor genes originated in the bacteria, or whether the enzyme synthetic genes in the bacteria are integrated segments of an $\mathbf{R}$ factor genome. In any event, the picture that is being developed for the origin of $R$ factors is that of a complex 'quilt' of genes of multiple origins brought together by multiple recombinational events under the selectial pressure of antibiotics in the environment.

\section{REFERENCES}

1 D. T. Dubin and B. D. Davis. Biochim. Biophys. Acta 74, 474 (1963).

2 B. Mach and E. L. Tatum. Science 139, 1051 (1963).

3 L. Leive. Biochem. Biophys. Res. Commun. 18, 13 (1965).

4 U. Taubeneck. Nature 196, 195 (1962).

${ }^{5}$ L. B. Sabath. Antimicrobial Agents and Chemotherapy-1967 210 (1968).

${ }^{6}$ E. Wolinsky and W. Steenken, Jr. Proc. Soc. Exp. Biol. Med. 62, 162 (1946).

D. W. Bentley, J. J. Hahn and M. H. Lepper. J. Infect. Diseases 122, 365 (1970).

8 D. H. Smith. International Symposium on Infectious Multiple Drug Resistance. Georgetown University School of Medicine. United States Government Press (1970).

9 J. Marmur. J. Mol. Biol. 3, 208 (1961).

10 S. Falkow, R. V. Citarella, J. A. Wohlhieter and T. Watanabe. J. Mol. Biol. 17, 102 (1966). 


\section{THE RESISTANCE OF BACTERIA TO ANTIBACTERIAL DRUGS}

11 R. Round, R. Nakayo and A. Nakamura. J. Mol. Biol. 17, 376 (1963).

12 T. Nisioka, M. Mitani and R. Clowes. J. Bacteriol. 97, 376 (1969).

13 S. Falkow, D. K. Haapala and R. P. Silver. Bacterial Episomes and Plasmids J. A. Churchhill, Ltd. London (1969).

14 S. N. Cohen and C. A. Miller. J. Mol. Biol. 50, 671 (1970).

15 H. I. Adler, W. D. Fisher, A. Cohen and A. A. Hardigee. Proc. Nat. Acad. Sci. US 57, 321 (1967).

16 S. Levy and P. Norman. Nature 227, 606 (1970).

17 T. Watanabe. Bacteriol. Rev. 27, 87 (1963).

18 E. S. Anderson and M. J. Lewis. Nature 208, 843 (1965).

19 S. N. Cohen and C. A. Miller. Proc. Nat. Acad. Sci. US 67, 510 (1970).

20 M. Okada and T. Watanabe. Nature 217, 854 (1968).

21 E. Meynell and N. Datta. Nature 214, 885 (1967).

22 E. Meynell, G. G. Meynell and N. Datta. Bacteriol. Rev. 32, 55 (1968).

${ }^{23}$ S. Mitsuhashi. Gunima J. Med. Sci. 14, 169 (1965).

24 T. C. Salzman and L. Klemm. Proc. Soc. Exp. Biol. Med. 128, 392 (1963).

${ }^{25}$ M. H. Hane and T. H. Wood. J. Bacteriol. 99, 238 (1969).

26 D. H. Smith and S. Armour. Lancet. ii, 15 (1966).

27 S. A. Shroeder, P. M. Terry and J. V. Bennett. J. Amer. Med. Ass. 205, 903 (1968).

28 A. C. Gunter and T. W. Feary. J. Bacteriol. 96, 1556 (1968).

29 K. G. Eriksson-Greenberg, H. G. Boman, J. A. Torbjörn Jansson and S. Thorën. J. Bacteriol. 90, 54 (1965).

30 W. V. Shaw. J. Biol. Chem. 242, 687 (1967).

31 D. Sompolinsky and Z. Samra. J. Gen. Microbiol. 50, 55 (1968).

32 O. Doi, M. Ogura, N. Tanaka and H. Umezawa. Appl. Microbiol. 16, 1276 (1968).

33 Y. Suzuki and S. Okamoto. J. Biol. Chem. 242, 4722 (1967).

${ }^{34}$ W. V. Shaw and R. F. Brodsky. Antimicrobial Agents and Chemotherapy-1967 257 (1968).

${ }^{35}$ D. Vasquez. Biochim. Biophys. Acta 114, 277 (1966).

36 W. V. Shaw and J. Unowsky. J. Bacteriol. 95, 1976 (1968).

37 S. Okamoto, Y. Suzuki, K. Mise and R. Nakaya. J. Bacteriol. 94, 1616 (1967).

38 H. W. Jacobsen, Jr. and W. V. Shaw. Bacteriol. Proceedings, p. 60. (1970).

39 W. V. Shaw and R. F. Brodsky. J. Bacteriol. 95, 28 (1968).

40 W. V. Shaw, D. W. Bentley and L. Sands. J. Bacteriol. 104, 1095 (1970).

41 J. Harwood and D. H. Smith. Biochem. Biophys. Res. Commun. 37, 57 (1971).

42 H. Umezawa, S. Takasawa, M. Okanishi and R. Utahara. J. Antibiotics (Tokyo) 21, 81 (1968).

${ }^{43}$ T. Yamada, D. Tipper and J. Davies. Nature 219, 288 (1968).

44 J. Harwood and D. H. Smith. J. Bacteriol. 97, 1262 (1969).

45 J. E. Davies, P. W. Anderson and B. D. Davis. Science 149, 1096 (1965).

46 B. Ozanne, R. Benveniste, D. Tipper and J. Davies. J. Bacteriol. 100, 1144 (1969).

47 J. Davies, R. Benveniste, K. Kvitek, B. Ozanne and T. Yamada. J. Infect. Diseases 119, 351 (1969).

48 O. Doi, M. Migamoto, N. Tanaka and H. Umezawa. Appl. Microbiol. 16, 1282 (1968).

${ }^{49}$ H. Umezawa, M. Okanishi, R. Utahara, K. Maeda and S. Kondo. J. Antibiotics (Tokyo) 20 , $136(1967)$.

50 S. Kondo, M. Okanishi, R. Utahara, K. Maeda and H. Umezawa. J. Antibiotics (Tokyo) 21, 22 (1968).

51 D. J. Cooper, H. M. Marigliano, M. D. Yudis and T. Traubel. J. Infect. Diseases 119, 342 (1969).

52 G. W. Jack and M. H. Richmond. J. Gen. Microbiol. 61, 43 (1970).

53 A. A. Medeiros and T. F. O'Brien. Antimicrobial Agents and Chemotherapy-1966 321 (1967).

54 V. Hinshaw, J. Punch, M. J. Allison and H. P. Dalton. Appl. Microbiol. 17, 214 (1969).

55 B. Slocombe and R. Sutherland. Antimicrobial Agents and Chemotherapy-1969 78 (1970).

56 E. J. Lowbury, A. Kidson, H. A. Lilly, G. A. J. Ayliffe and R. J. Jones. Lancet ii, 448 (1969).

57 R. B. Sykes and M. H. Richmond. Nature 226, 952 (1970).

58 P. D. Fullbrook, S. W. Elson and B. Slocombe. Nature 226, 1054 (1970).

59 M. Lachmajer and M. Bobrowski. Arch. Immunol. Therap. Exp. 17, 633 (1969).

60 P. Fredericq. Bacterial Episomes and Plasmids J. A. Churchhill, Ltd. London, p. 163 (1969).

61 L. E. Pearce and E. Meynell. J. Gen. Microbiol. 50, 159 (1968).

62 J. Pitt and D. H. Smith. Bacteriol. Proceedings p. 60 (1970).

${ }^{63}$ R. Benveniste and J. Davies. FEBS Letters 14, 293 (1971). 